\title{
Conclusion: Mummers to Madness- the broader picture
}

Enjoy yourself it's later than you think

Enjoy yourself while you're still in the pink.

The years go by as quickly as a wink

Enjoy yourself, enjoy yourself

It's later than you think.

Madness, 'Enjoy Yourself (It's Later Than You Think)'

\section{Continuity or change?}

EIGHTEENTH CENTURy MUMmers, setting out on their village perambulations at Christmas or Easter, performing their often limited repertoire of 'traditional' songs and dances on pipes and tabors, maybe a fiddle, to a small, parochial audience, were a world away from Madness, on tour across the country, singing a mixture of ska-inspired and music-hall-influenced hits, old and new, accompanied by electric keyboard and saxophone, to a stadium audience that ran to thousands.Various 'revolutions,' socio-economic and cultural, transformed the context in which popular music operated. A range of technological developments, pioneered in the late nineteenth century and applied increasingly across the twentieth, transformed the production and consumption of music.

Until the early twentieth century, live performance was central, whether it be for a professional music hall artiste or an itinerant barrel-organ player, or even for the amateur performer at home or in an ale house. Their instruments were 
acoustic, but volume was at a premium, whether playing at a fairground or in a dancing booth. Singers, likewise, needed to generate sufficient volume to capture the attention of an early music hall audience, or drown out its chatter. The invention and development of the microphone allowed for the development of new styles of singing; the development of electrified instruments, notably guitars and keyboards, and the use of amplifiers made easier the task of filling a room with sounds and made possible new sounds. Indeed, recording techniques developed to such an extent that by the late 1960s a band could make a musical sound that could not be recreated on stage. Alongside this professional music-making was an important, but easily overlooked, tradition of amateur music making, often of surprising quality. For those with the wherewithal (or good fortune) to acquire an instrument and the ability to play it, there were a range of relatively (and increasingly) cheap instruments - fiddles, whistles, pianos, concertina, guitars. And there was also the most accessible and portable musical instrument - the voice.

If the production of music was transformed by technology, so too was its consumption. Until the turn of the twentieth century, live performance was also central to the listening experience, irrespective of venue. Thereafter, the situation changed fundamentally. The advent of radio, television and film greatly increased the range and quality of available music and the convenience with which it could be heard. No longer was it necessary to go the local variety theatre, or even the local working man's club. The development of the wax cylinder, records $(78,45$ and $33 \mathrm{rpm})$, cassettes and compact discs made music repeatable and portable, even if there was a price to be paid in terms of sound quality. The sound quality of recorded music was steadily improved as gramophones morphed into music centres. By the 1960s records were at the centre of popular music consumption. There was still an important role for live performance, not least because of the collective experience, but the quasi-monopoly position it enjoyed c. 1900 had been undermined.

And yet for all these dramatic changes, and the very different periods and contexts in which popular music developed, there was an important element of continuity in terms of the range 
of functions it performed over the two centuries covered by this book. Both individually and collectively, it provided means of exploring and expressing a range of profound emotions. It could entertain or educate. The physical and emotional experience of singing, playing or dancing, created opportunities for self-expression and self-discovery of social and political identities. Such were the complexities of performance, for performers and audience members, and the differing meaning ascribed to or derived from a performance, not to mention the limitations of evidence, especially in the earlier years, that its specific significance and impact will remain a matter of ongoing debate. However, there is an underlying continuity in terms of artistic, social and political functions associated with popular music and of the recurring issues explored by it.

\section{Some possible patterns, broader themes and unanswered questions}

The often-serendipitous changes that took place and the sheer untidiness of popular music, which defies clear-cut definition, categorisation and explanation, makes generalisation hazardous, but it is necessary to stand back from the detail considered in previous chapters. Two overviews suggest themselves, which offer framework within which to explore the twoway interaction between popular music and society. The first, more descriptive, focuses on the music-hall/variety tradition. Most of the basic elements ofVictorian and Edwardian musichall were pre-figured in late-eighteenth and early-nineteenth century England and the emergence of music hall, as a location as much as a form of entertainment, in the 1840s and 1850s was a logical development of popular entertainment in the changing socio-economic context of early Victorian England. Although there was more to nineteenth-century popular music than music hall, it stood stage centre. The protracted decline of variety theatre in the twentieth century reflected its adaptability and tenacity. But if the nineteenth century had witnessed a concentration of elements previously found in distinct locations, the twentieth century saw a relocation (and romanticisation) of music hall in radio and television, as well as a dispersal of certain elements into other forms of popular music. The development of popular dancing was not dissimilar. The portable dancing booths of the eighteenth century were 
superseded by the dancing saloons and, more so, dance halls of the nineteenth and twentieth.

The second, more interpretative, would focus on interactions between different musical traditions and emphasise the importance of musical accommodation and fusion. It sets the development of English popular music in a context that embraces musical interchange and adaptation both within the nations (and regions) of the United Kingdom and, increasingly, within the Atlantic cultural trade network through which American, African-American and later African-Caribbean music influenced the development of popular music from the 1840s onwards.

The emphasis on cultural interaction raises several important questions relating to authenticity and appropriation. Whether related to Northumbrian piping, American blues or Jamaican reggae, claims that there is an essential or pure form are difficult to reconcile with the diverse roots of these (and other) genres and their continuing evolution in terms of repertoire, playing style and instrumentation. Purist cries of 'betrayal,' be directed at Muddy Waters or Marley, let alone Dylan, fail to do justice to musical dynamism and creativity.They also fail to recognise the economic realities facing many musicians. More importantly, they overlook the way in which musical 'compromise' (or fusion) created a wider market for that music and a gateway to its antecedents. Seeking to confine a musical genre to its 'authentic' form is the equivalent of preserving in aspic a museum specimen. Similarly, claims such that 'white men can't sing the blues' or 'only the Irish can play the union pipes' both oversimplify the history of these (and other) genres and overlook clear evidence to the contrary. More problematic is the relationship between cultural fusion, cultural appropriation and commercialization. There are some clear-cut examples of insensitive appropriation and misrepresentation of African American and Irish popular music, for example, but should early Elvis or UB40, for example, be seen simply as appropriators of African American blues and African Caribbean reggae? Or should they be seen as developers and popularizers, bringing hitherto little-known music to a wider audience and thereby extending the bounds of popular music? Similarly, should they be criticised for making a commercial success of music that 
had been performed sung by black artists for years with little recognition or reward? Or should they be seen as part of a long tradition of commercial popular music, traceable back to the eighteenth century?

The popularisation of rhythm and blues or reggae, and the emergence of new audiences raises questions about the meaning ascribed to popular music and its relationship with identities, from the individual to the national. On a number of occasions, particularly the years of the French and Napoleonic wars, the age of high Imperialism and during the second world war, popular music, in part at least, was explicitly linked with national identity, couched in terms of Englishness or Britishness that offered an image of unity that transcended regional and class, though not always religious, differences. The patriotic songs of the 1790s and 1800s, the jingoistic songs of the late-Victorian years and stoical yet sentimental songs of Flanagan and Allen, orVera Lynn, were active attempts to construct and manipulate a national identity; but they were not always successful. There was not a single interpretation of 'Britons, strike home,' nor a uniform response to MacDermott's 'Jingo Song.'

Indeed, the extent to which men and women thought (and sung) in national terms should not be overstated. Notions of England dissolve in the face of north/south rivalries but even these regional cultural identities were fissiparous. The Pennines was (and still is) an important physical and cultural barrier, while the followers of 'Trelawney's Army' had little love for their supposedly fellow west-countrymen in Devon. Local rivalries point to the persistence of parochialism in modern, urban society, not fundamentally dissimilar from earlier customs in which local identity and parochial superiority were asserted. Though the old parishes were swamped by the rapidly growing towns and cities, the traditions of communal singing in a variety of venues, including working men's clubs, pubs, football terraces as well as the home, created a sense of localised community. The 'village' survived in town and city. This sense of local identity was also true of various youth subcultures, particularly after the second world war. They were characterised by distinctive musical styles, as well as distinctive appearance, which distinguished themselves from the status quo, both socio-political and cultural, but also from each other. 
It is no coincidence that many of these groups had very strong local ties to specific districts, particularly in London.

Similarly, many of the minority immigrant communities never bought into this English national identity. Indeed, for the Irish from the mid-nineteenth century and West Indians later, music was a source of identity and as a means of coming to terms with living in a hostile 'host' environment. With succeeding generations, this process became more complex as hyphenated, dual heritage identities developed. For generations born in England it was difficult to talk meaningfully of home in Tralee or Trinidad but there was not a uniform response. For some the preservation of distinctive 'traditional' music and dance was of paramount importance in maintaining a distinct identity. But for others there was no such imperative. On the contrary, it was a culture that could be modified and popularised to the point that 'Danny Boy' and 'The Wild Rover,' or 'O Carolina' and 'Cherry Oh Baby' became part of a shared, communal songbook.

Popular music also contributed to a more personal sense of identity. At the risk of over-intellectualisation, certain, though not all, popular songs addressed a variety of issues, from the highly personal (love and marriage) to the societal (class relations and law enforcement). It would be naïve to treat popular songs as unproblematic indicators of values and attitudes, not least given the commercial influences at work, but it would be equally naive to assume that they had no meaning to their various consumers. Meaning was most clearly seen in social-commentary or political songs, condemning callous factory owners or tyrannous rulers, but even the most insipid 'love and marriage' song of the 1930s or 1950s carried an ideological content with which the listener could engage, in one way or another.

The meaning, or ideological content, of songs leads to a consideration of popular music, in its various forms and venues, as a site of tension and conflict. Throughout the two hundred years considered in this book plebeian music and dance was viewed, largely from above, as problematic. The prospect of young people, especially from the working classes, enjoying each other's company with limited or no supervision aroused fears in the breasts of moral reformers, even sympathetic social 
observers, not to mention generations of parents. And these were fears that could be stoked by overzealous pamphleteers and unscrupulous journalists. In recurring panics about the corrupting influences of popular music, the same themes recur. Dances are at best clumsy and inelegant, at worst, unrestrained, salacious or indecent. Songs are inane, suggestive, if not downright lewd and subversive of authority. And these shortcomings were compounded by being associated with foreigners, from the licentious French, the foppish Italian to the animalistic 'negro.' Such were these fears that various expedients were used to control the threat to morality. Some were unsubtle in their use of the law and the police; others were more imaginative in attempting to tame savage song or dance with decorous, respectable alternatives; neither tactic was particularly successful. The key was in the title: 'popular music.' As long as a dance or a song was popular, for whatever reason (including the very fact that someone was trying to ban it), it was difficult for authorities, in whatever form, to suppress it. Moral reformers preached to the converted, while those whom they sought to convert largely ignored them. Moralistic entrepreneurs, seeking to make respectable the content of the acts on stage, had limited influence, even within, let alone beyond their theatres. The BBC could ban Judge Dread from their airwaves, but they could not stop people buying his records in large numbers. Police (not the band) were too few in number, and too aware of the dangers of antagonising large crowds of men and women enjoying themselves, to act in any but the most serious breaches of the peace; and many magistrates were well aware of this too.

More to the point, fears were often grossly overstated or untypical. From eighteenth-century ballads, through musichall favourites to twentieth-century pop songs, many were conservative in sentiment, supportive of marriage and 'traditional' gender roles, and condemnatory of crime, especially crimes of violence. Likewise, many dancing saloons in the nineteenth century and most dance halls in the twentieth, were more decorous, more respectable and more self-policed than lurid accounts of depravity would have us believe. This did not mean that there were not tensions. Young men and women went to dances, in part at least, to meet a partner and all that that entailed. 
'Come lasses and lads, away from your dads,' was a sentiment that echoed down the ages, even though their concerned parents had done the same. Alcohol was consumed, often excessively and illegally, at nineteenth century fairs and twentieth century village hops, but the practice was widely tolerated. Other harmful substances, some legal some not, were consumed, but, as in the case of cigarettes, these were often tacitly approved rites of passage. The privatisation of music consumption after the second world war may have reduced some of these problems, though the number of hastily opened bedroom windows suggests that it was not just music that was being consumed. Successive generations, literally and metaphorically, made 'a song and dance,' particularly about rites of passage associated with the transition to adulthood that they themselves had been through, but whatever the fears of reformist critics, there were widely-accepted and widelyobserved popular codes of behaviour. The high-profile panics of the past, the cries of generational conflict and moral collapse, should not obscure the fact that consensus was as much a feature of popular music as confrontation. There is little evidence to suggest a widespread abandonment of societal norms. Indeed, in a broad sense, and not least driven by commercial imperatives and the need to appeal to a wide audience, the contours and contents of popular music were shaped in no small measure by the norms and values of society at large.

While much can be learned about popular attitudes in times past through the study of popular music there is much that remains unknown. We will never know how many people attended the music halls, singing saloons and dance saloons of Victorian England. We will never know the number of people who heard a music hall hit as it was sung or played in the streets, on the beach and at the fair. Nor will we know how many people played a tune as the sheet music was passed around and sold second hand, or how many people listened to (rather than bought) the hit records of the twentieth century. And how do we put figures on the singing, dancing and playing that took place in workingmen's clubs, public houses and homes? More importantly, how do we capture the totality of a performance in the absence of physical presence? Music and lyrics might be available in a variety of forms, but they are only part of the overall experience. How are we to explore the meaning given 
by audiences, themselves not homogenous, to a performance? Performances were often complex, with implicit as well as explicit meaning, which audiences could 'read' in a variety of ways that remain hidden to the historian.

It would be wrong to end on a negative note. As well as establishing the broad outlines of the evolution of popular music in modern England, this study has explored the broader contexts within which it developed and with which it interacted; and in so doing, has shown the varied and important functions of popular song and dance. Easy to dismiss as lightweight, inauthentic and ephemeral, 'popular' music was precisely that - popular; and in exploring the reasons for this popularity it is possible to gain insights into important aspects of everyday life in times past. However, a sense of proportion is called for. Popular music was produced and, more importantly, consumed, not for the benefit of later historians, but for enjoyment at the time. Remember Madness: 'Enjoy yourself! It's later than you think.' 1

\section{Endnotes}

1 Prince Buster, Suggs and Georgie Fame, 'Enjoy Yourself' https://www.youtube. $\mathrm{com} /$ watch?v $=$ WE8FATuziSc 